\title{
Rancang Bangun Sistem Rekomendasi Televisi LED Dengan Metode Vikor Berbasis Web
}

\author{
Boyma Simamora \\ Fakultas Teknik dan Informatika, Universitas Multimedia Nusantara, Tangerang, Indonesia \\ boyma.simamora@student.umn.ac.id
}

Diterima 19 Mei 2017

Disetujui 19 Juni 2017

\begin{abstract}
Beragam macam pilihan televisi LED membuat pembeli mengalami kebingungan saat menentukan tipe televisi LED yang akan dibeli. Beberapa merk televisi terkenal menawarkan macam-macam tipe televisi LED dengan keunggulannya masing-masing. Perbedaan dapat dilihat dari segi harga, ukuran layar, resolusi layar, berat dan fasilitas pendukung lain yang diberikan. Sehingga dibuatlah sistem rekomendasi pembelian televisi LED untuk memberikan masukan dan bantuan kepada calon pembeli sebagai bahan pertimbangan sesuai dengan keinginannya. Penggunaan metode VIKOR diterapkan karena termasuk jenis dari Multi Criteria Decision Making untuk mengambil keputusan bersifat diskrit berdasarkan beberapa kriteria dan membantu pengambil keputusan sebagai hasil terbaik dari rekomendasi sistem. Kriteria yang digunakan yaitu rentang harga, merk, resolusi layar, ukuran layar, berat dan fasilitas sebagai deskripsi televisi. Pembuatan sistem dibangun dengan menggunakan bahasa pemrograman PHP dan database MySQL. Uji Kepuasan Pengguna Sistem dilakukan dengan melakukan survei kepada 30 responden dengan menggunakan metode Likert dan Cronbach Alpha. Hasil yang diperoleh sebesar 0,72 dan dapat disimpulkan dalam kategori cukup baik.
\end{abstract}

Index Terms-Televisi LED, Sistem Rekomendasi, VIKOR, Skala Likert, Cronbach Alpha.

\section{Pendahuluan}

Kebutuhan akan adanya informasi, hiburan dan pendidikan diperlukan untuk menambah pengetahuan seseorang. Hal itu didapat dari salah satu alat elektronik yaitu televisi. Televisi adalah sistem elektronik yang mengirimkan gambar diam dan gambar hidup bersama suara melalui kabel dan ruang [1]. Televisi dapat dimanfaatkan untuk keperluan pendidikan, yang sangat mudah dijangkau melalui siaran udara.

Media televisi dinilai sebagai media yang paling sering diakses oleh masyarakat Indonesia. Penelitian dilakukan oleh MarkPlus mengenai media yang paling sering diakses oleh kaum muda pada 6 bulan terakhir pada 2014 di 10 Kota di Indonesia [2]. Hasil menunjukkan bahwa media yang paling sering diakses adalah media televisi dengan perolehan sebesar $100 \%$, ini menunjukkan bahwa seluruh responden mengakses televisi.
Menurut lembaga survei AC Nielsen [3], tingkat konsumsi media di lima kota besar di luar Pulau Jawa lebih tinggi dibandingkan kota besar di Pulau Jawa. Secara keseluruhan menunjukkan bahwa televisi masih menjadi medium utama yang dikonsumsi masyarakat Indonesia di perkotaan khususnya pada Pulau Jawa maupun luar Jawa, yaitu sebesar 95\%, disusul oleh internet dengan $33 \%$, radio $20 \%$, surat kabar $12 \%$, tabloid $6 \%$ dan majalah 5\%.

Kemudian, pada 2014 KOMINFO mengadakan survei akses dan pengguna indikator TIK sektor rumah tangga. Sampel dalam survei ini berjumlah 9.680 rumah tangga dengan tingkat keyakinan $95 \%$ dan margin of error estimation sekitar $1 \%$. Berdasarkan hasil survei akses TIK di rumah tangga, persentase kepemilikan radio di rumah tangga Indonesia hanya sebesar $27,2 \%$, telepon kabel 5,8\% dan mayoritas rumah tangga Indonesia memiliki televisi sebesar 87,20\% [4]. Hal tersebut menunjukkan bahwa televisi merupakan perangkat TIK paling banyak dimiliki dan penting untuk masyarakat Indonesia.

Televisi sebagai salah satu media elektronik yang digunakan masyarakat Indonesia berkembang seiring dengan perkembangan teknologi dan kebutuhan akan televisi. Pada tahun 2006 diproduksi televisi LED berbasis DLP (Digital Light Processing) HDTV pertama. televisi LED (Light Emitting Diodes) merupakan pengembangan dari LCD (Liquid Crystal Display) TV yang menggunakan LED Backlight sebagai pengganti cahaya fluorescent pada LCD TV [5].

Secara umum televisi LED menawarkan kualitas gambar yang baik khususnya, contrast, konsumsi listrik yang lebih sedikit dibandingkan LCD dan ramah lingkungan. Televisi LED memungkinkan produsen untuk memproduksi televisi dengan layar yang berukuran tipis. Sehingga televisi LED menjadi salah satu produk pilihan perangkat elektronik yang paling digemari oleh banyak orang.

Namun sering sekali calon konsumen mengalami kebingungan saat memilih tipe televisi LED yang akan dibeli [6]. Adapun faktor yang menyebabkan 
kebingungan dalam memilih televisi LED adalah adanya beberapa merk yang menawarkan macammacam tipe televisi dengan berbagai macam spesifikasi televisi (inches), resolusi, USB, HDMI, output audio, VGA output, TV System, harga, dan daya (watt) [6]. Oleh karena itu, dibutuhkan sebuah sistem rekomendasi pembelian televisi LED untuk membantu calon konsumen membeli televisi LED sesuai dengan kebutuhan dari kriteria-kriteria yang diinginkan. Kriteria-kriteria yang digunakan yaitu harga, merk, resolusi layar, ukuran layar, berat dan fasilitas berdasarkan hasil kuesioner dari Sistem Pendukung Keputusan untuk Merekomendasikan TV Layar Datar Menggunakan Metode Weighted Product [7].

Metode VIKOR merupakan metode Multi-Criteria Decision Making (MCDM) yang dapat digunakan untuk menyeleksi lebih dari satu kriteria, kemudian akan dilakukan proses menyeleksi hasil yang terbaik. Sehingga diharapkan dapat membantu proses pembelian televisi LED yang tepat sesuai kriteria-kriteria yang telah ditentukan.

Terdapat beberapa penelitian sebelumnya yang telah menggunakan metode VIKOR dalam pemilihan robot industri untuk penggunaan secara spesifik pada aplikasi teknik [8]. Pemilihan robot industri merupakan salah satu masalah yang paling menantang pada saat proses menentukan keputusan robot industri yang paling tepat sesuai tujuan dan biaya seminimal mungkin dan kemampuannya secara spesifik. Dari hasil penelitian tersebut menunjukkan metode VIKOR mampu memilih robot yang tepat berdasarkan hasil seleksi. Lalu, penelitian implementasi metode VIKOR untuk seleksi penerimaan beasiswa yang menunjukkan bahwa metode VIKOR dapat membantu proses seleksi dan menentukan penerimaan beasiswa yang tepat, serta membuat hasil terbaik kompromi alternatif dari sejumlah alternatif [9].

Penggunaan metode VIKOR untuk pembangkit listrik tenaga air (PLTA) berkelanjutan dengan 56 kriteria disederhanakan menjadi 23 kriteria kemudian menggunakan metode VIKOR untuk membuat perankingan terhadap alternatif yang ada. Hasil penelitian menunjukkan bahwa metode VIKOR dapat membantu pembuatan keputusan dalam proses desain, menyediakan dukungan untuk pemilihan tempat dan parameter operasi [10]. Pada penelitian yang membandingkan antara metode TOPSIS dan VIKOR menyimpulkan bahwa metode VIKOR lebih mendekati titik solusi ideal dengan menggunakan normalisasi linear dibandingkan dengan metode TOPSIS yang menggunakan normalisasi vektor [11].

Berdasarkan pemaparan-pemaparan tersebut maka, dipilih metode VIKOR untuk digunakan dalam penelitian pada sistem rekomendasi pembelian televisi
LED. Penggunaan metode VIKOR diharapkan dapat membantu calon konsumen dapat dalam memilih televisi LED yang sesuai dengan kriteria dan kebutuhannya.

\section{KAJIAN PUSTAKA}

\section{A. Sistem Rekomendasi}

Sistem rekomendasi adalah sebuah sistem yang dapat memberikan rekomendasi kepada para pengguna sistem yang akan dibuat [12]. Rekomendasi yang diberikan dapat berdasarkan karakteristik dari data pengguna tersebut. Sedangkan dalam mengumpulkan data untuk pembuatan sistem rekomendasi dapat dilakukan secara langsung dan tidak langsung [13].

\section{B. Multi Criteria Decision Making (MCDM)}

Multi-Criteria Decision Making (MCDM) adalah suatu metode pengambilan keputusan untuk menetapkan alternatif terbaik dari sejumlah alternatif berdasarkan beberapa kriteria tertentu. Kriteria biasanya berupa ukuran-ukuran atau aturan-aturan atau standar yang digunakan dalam pengambilan keputusan. Secara umum, tujuan MCDM menyeleksi alternatif terbaik dari sejumlah alternatif [14]. Berdasarkan tujuannya metode MCDM memiliki dua model yaitu Multi Attribute Decision Making (MADM) untuk menyeleksi alternatif terbaik dari sejumlah alternatif dan Multi Objective Decesion Making (MODM) untuk merancang alternatif terbaik [15].

\section{Metode VIKOR}

VIKOR (VlseKriterijumska Optimizacija I Kompromisno Resenje dalam bahasa Serbia, yang artinya Multicriteria Optimization dan Compromise Solution) adalah metode perankingan dengan menggunakan indeks peringkat multikriteria berdasarkan ukuran tertentu dari kedekatan dengan solusi yang ideal. Metode VIKOR merupakan salah satu metode yang dapat dikategorisasikan dalam Multicriteria decision analysis [17]. Metode VIKOR dikembangkan sebagai metode multicriteria decision making untuk menyelesaikan pengambilan keputusan bersifat diskrit pada kriteria yang bertentangan dan noncommensurable (tidak ada cara yang tepat untuk menentukan mana yang lebih akurat) [18].

Metode VIKOR fokus pada perankingan dan memilih dari satu set sampel dengan kriteria yang saling bertentangan, yang dapat membantu para pengambil keputusan untuk mendapatkan keputusan akhir [18]. Metode ini sangat berguna pada situasi dimana pengambil keputusan tidak memiliki kemampuan untuk menentukan pilihan pada saat desain sebuah sistem dimulai [19]. 
Metode VIKOR adalah sebuah metode untuk optimisasi/optimalisasi kriteria majemuk dalam suatu sistem yang kompleks [20]. Konsep dasar VIKOR adalah menentukan ranking dari sampel-sampel yang ada dengan melihat hasil dari nilai-nilai sesalan atau regrets $(\mathrm{R})$ dari setiap sampel. Metode VIKOR telah digunakan oleh beberapa peneliti dalam MCDM, seperti dalam pemilihan vendor [21], perbandingan metodemetode outranking [18], pemilihan bahan dalam industry [22]. Masih banyak penelitian-penelitian yang menggunakan metode VIKOR ini.

Langkah-langkah yang digunakan dalam Metode VIKOR adalah sebagai berikut [23]:

\section{Tabel pengamatan}

Dari data yang didapat pada database digunakan menjadi data untuk tabel pengamatan, lalu menentukan nilai data terbaik $\left(f_{i}^{*}\right)$ dan terburuk $\left(f_{i}^{-}\right)$atau dengan istilah Cost dan Benefit dalam satu variabel penelitian. Penentuan data terbaik dan terburuk ditentukan oleh jenis data variabel penelitian higher-the-better (HB) atau lower-the-better (LB) [23].

\section{Bobot kriteria}

Menentukan bobot kriteria yang diperoleh dari pengguna sistem sesuai dengan kebutuhan atau kriteria yang diinginkan.

3. Normalisasi matriks [23].

2.1)

$$
\mathrm{R}_{\mathrm{ij}}=\frac{\left(f_{i}^{*}\right)-\left(f_{i j}\right)}{\left(f_{i}^{*}\right)-\left(f_{i}^{-}\right)}
$$

dimana :

$\mathrm{R}_{\mathrm{ij}}=$ nilai normalisasi sampel $i$ kriteria $j$

$f_{i j}=$ nilai data sampel $i$ kriteria $j$

$f_{i}^{*}=$ nilai terbaik dalam satu kriteria

$f_{i}^{-}=$nilai terjelek dalam satu kriteria

4. Normalisasi bobot $\left(\mathrm{W}_{\mathrm{j}} \times \mathrm{R}_{\mathrm{ij}}\right)$

Melakukan perkalian antara nilai data yang telah dinormalisasi dengan nilai bobot kriteria yang telah ditentukan.

5. Menghitung nilai Utility Measure $(S)$ dan Regret Measure $(R)[11]$

2.2)

$$
\mathrm{S}_{\mathrm{j}}=\sum_{j=1}^{n} \mathrm{~W}_{\mathrm{i}}\left(\frac{\left(f_{i}^{*}\right)-\left(f_{i j}\right)}{\left(f_{i}^{*}\right)-\left(f_{i}^{-}\right)}\right)
$$

$\mathrm{R}_{\mathrm{j}}=\operatorname{Max}_{\mathrm{j}}\left[\mathrm{W}_{\mathrm{i}}\left(\frac{\left(f_{i}^{*}\right)-\left(f_{i j}\right)}{\left(f_{i}^{*}\right)-\left(f_{i}^{-}\right)}\right)\right]$

dimana :

$\mathrm{W}_{\mathrm{j}}=$ bobot kriteria

6. Menghitung indeks VIKOR [11]
$Q_{j}=\left[\frac{S_{j}-S^{*}}{S^{-}-S^{*}}\right] \times v+\left[\frac{R_{j}-R^{*}}{R^{-}-R^{*}}\right] \times(1-v) \quad \ldots$ (Rumus 2.4)

dimana :

$\mathrm{S}^{*}=$ nilai $\mathrm{S}$ terkecil

$\mathrm{S}^{-}=$nilai $\mathrm{S}$ terbesar

$\mathrm{R}^{*}=$ nilai $\mathrm{R}$ terkecil

$\mathrm{R}^{-}=$nilai $\mathrm{R}$ terbesar

7. Perankingan alternatif [11]

Setelah $\mathrm{Q}_{\mathrm{j}}$ dihitung, maka Pengurutan perankingan ditentukan dari nilai yang paling rendah dengan solusi kompromi sebagai solusi ideal dilihat dari perankingan $Q_{j}$ dengan nilai terendah. Karena nilai $\mathrm{S}_{\mathrm{j}}$ merupakan solusi yang diukur dari titik terjauh solusi ideal, sedangkan nilai $\mathrm{R}_{\mathrm{j}}$ merupakan solusi yang diukur dari titik terdekat solusi ideal.

\section{Metode DAN PERANCANGAN Sistem}

\section{A. Flowchart}

Flowchart atau diagram alur adalah bagan-bagan yang memiliki arus untuk menggambarkan langkahlangkah dan proses pada suatu sistem. Flowchart pada sistem ini terdiri dari dua bagian yaitu flowchart untuk admin (backend) dan flowchart untuk user (frontend). Pada Gambar 3.1 menunjukkan alur proses pertama pada sistem rekomendasi ketika pertama kali membuka sistem ini. Pada Halaman Utama terdapat dua menu yang dapat digunakan oleh user yaitu, Menu Cari Rekomendasi dan Menu Tentang.

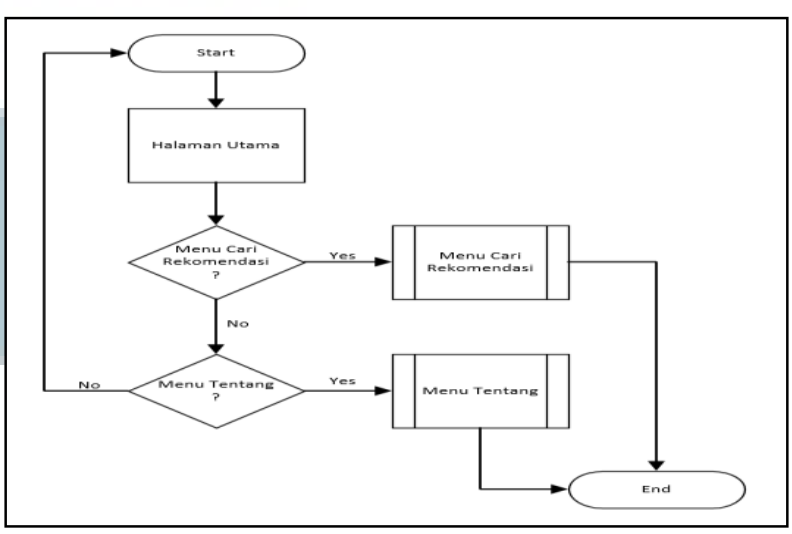

Gambar 3.1 Flowchart Menu Utama

Pada Gambar 3.2 menunjukkan alur proses yang dilakukan sistem ketika user melakukan proses cari rekomendasi. Dimulai dengan memilih referensi dan memasukkan input bobot kriteria kemudian nilai bobot akan masuk ke database dan dilakukan perhitungan dengan menggunakan metode VIKOR yang menghasilkan hasil rekomendasi berupa daftar televisi LED yang direkomendasikan oleh sistem. 


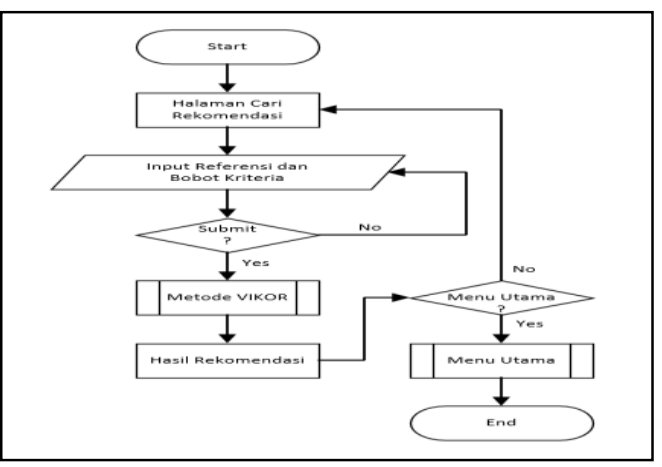

Gambar 3.2 Flowchart Menu Cari Rekomendasi

Pada Gambar 3.3 menjelaskan alur proses metode VIKOR. Awal proses dimulai dari inputan bobot kriteria dari user, menentukan data alternatif, menentukan nilai terbaik dari data alternatif dan terburuk dari data alternatif televisi LED. Dari data tersebut dilakukan normalisasi matriks pada data televisi dengan rumus, hasil normalisasi dikalikan dengan nilai bobot kriteria yang diinginkan dengan rumus. Dari perhitungan tersebut diperoleh nilai $\mathrm{S}$ dan nilai $R$ dengan rumus. Dari nilai $S$ dan nilai $R$ maka kita dapat mencari nilai $Q$ dengan rumus. Hasil nilai $Q$ yang didapat diurutkan berdasarkan dari nilai yang paling terkecil, untuk menentukan peringkat terbaik dari hasil rekomendasi menggunakan metode VIKOR.

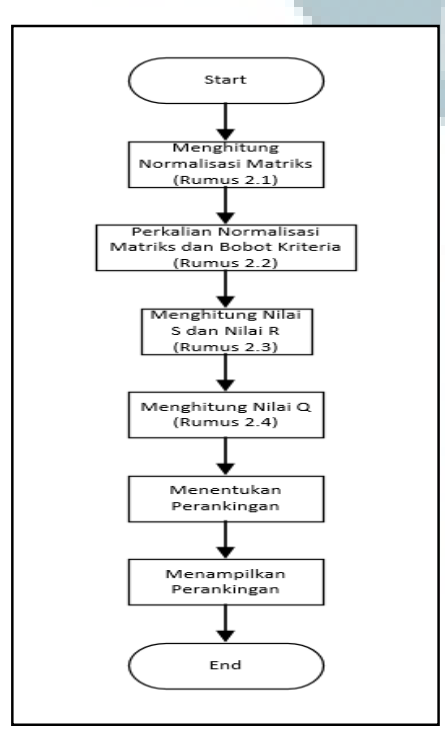

Gambar 3.3 Flowchart Metode VIKOR

Pada Gambar 3.4 menunjukkan alur proses saat admin memilih Menu Login pada sistem. Pada Menu Login harus memasukkan username dan password yang benar, setelah akan diverifikasi dari database tabel tb_login. Menu Analisa hanya dapat digunakan oleh admin untuk menambah, mengubah dan menghapus data produk televisi yang menampung perubahan ke dalam database, serta menampilkan semua data produk televisi.

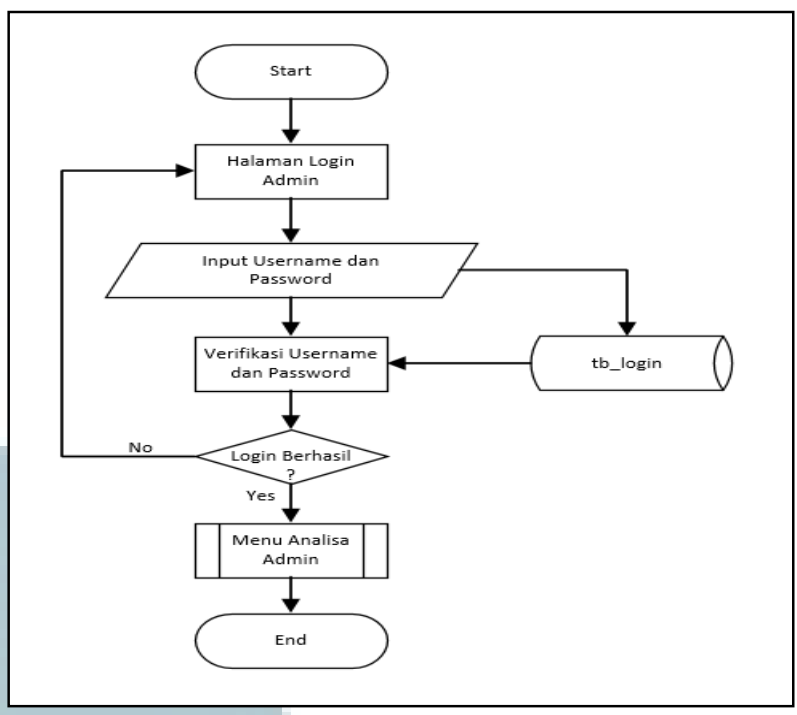

Gambar 3.4 Flowchart Menu Login Admin

Pada Gambar 3.5 menunjukkan alur proses saat admin memilih Menu Analisa pada sistem. Pada halaman Analisa terdapat tiga subproses yang dapat admin lakukan yaitu, Proses Tambah, Proses Ubah, dan Proses Hapus. Pada Proses Tambah dapat menambahkan data televisi, pada Proses Ubah dapat merubah data televisi yang sudah ditampilkan di halaman Analisa, dan untuk Proses Hapus dapat digunakan jika admin ingin menghapus data televisi yang ada pada halaman Analisa dan perubahan akan disimpan ke dalam database.

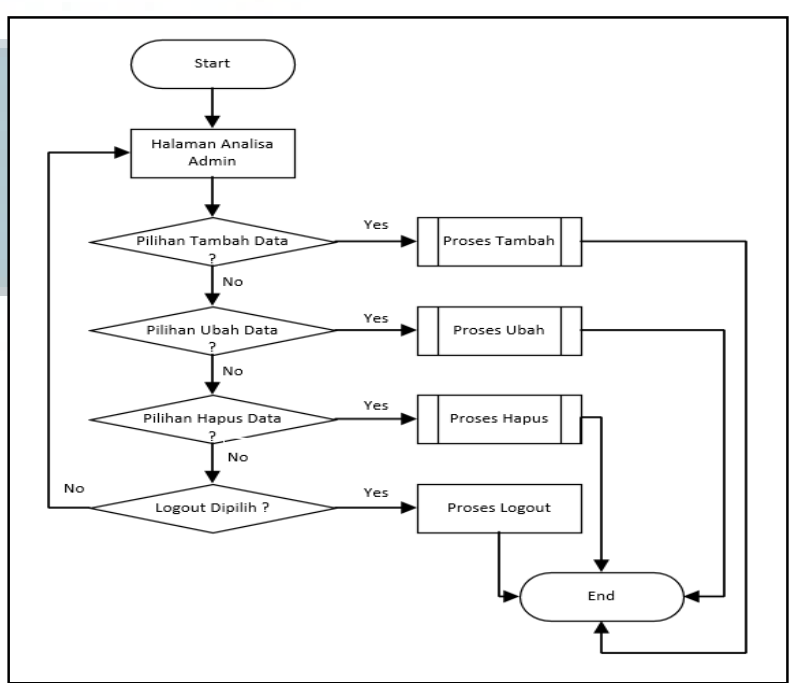

Gambar 3.5 Flowchart Menu Analisa Admin 
Pada Gambar 3.6 menunjukkan alur proses saat admin memilih proses Tambah pada sistem. Pertama akan ditampilkan halaman Tambah, kemudian admin dapat melakukan tambah data dengan malakukan input data televisi yang hanya dapat dilakukan oleh admin, jika berhasil melakukan penambahan data maka data yang telah diinput akan disimpan ke database.

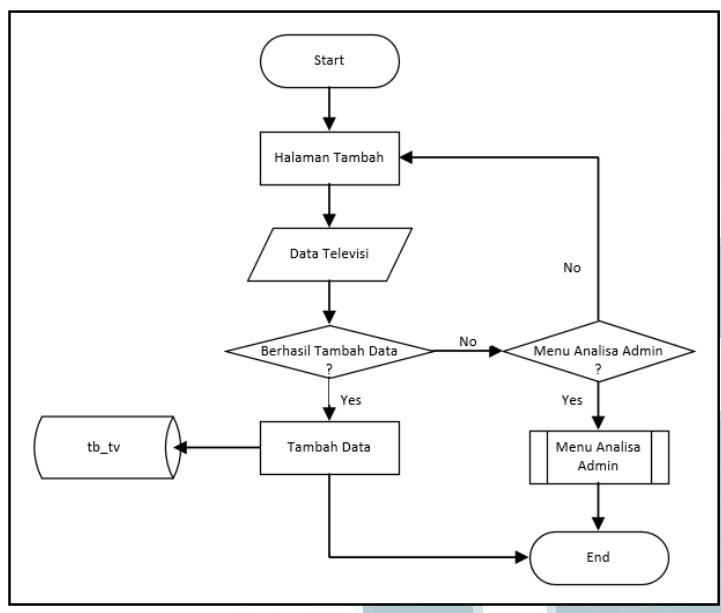

Gambar 3.6 Flowchart Proses Tambah

Pada Gambar 3.7 menunjukkan alur proses saat admin memilih proses Ubah. Pertama akan ditampilkan halaman Ubah yang berisi data televisi. Kemudian admin dapat melakukan Ubah data dengan memilih terlebih dahulu data yang ingin diubah dari tampilan daftar list televisi. Setelah data berhasil diubah maka data tersebut akan disimpan ke database pada tabel tb_tv. Selain itu terdapat pilihan untuk kembali ke Menu Analisa jika tidak menggunakan Proses Tambah, sehingga dapat memilih proses yang lain yang terdapat pada halaman Analisa pada sistem ini.

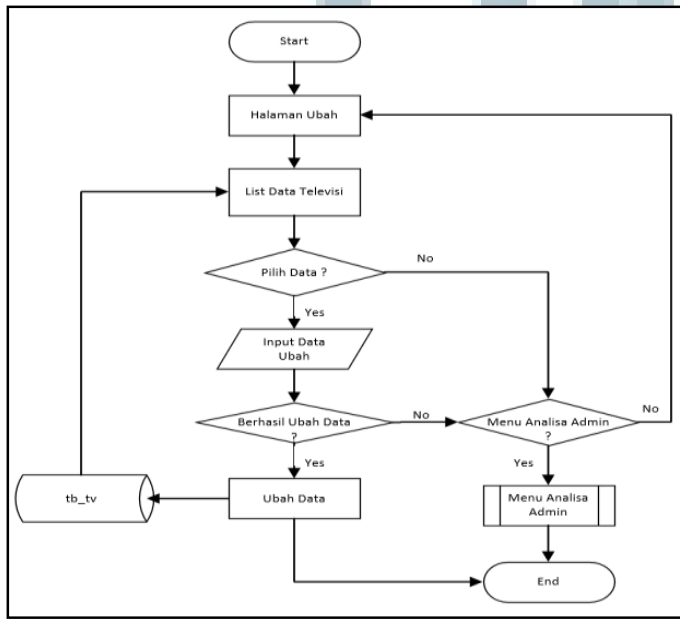

Gambar 3.7 Flowchart Proses Ubah
Pada Gambar 3.8 menunjukkan alur proses saat admin memilih proses Hapus pada sistem. Pertama akan ditampilkan halaman Hapus yang berisi data televisi. Kemudian admin dapat melakukan Hapus data dengan memilih terlebih dahulu data yang ingin dihpaus dari tampilan daftar list televisi. Setelah data berhasil dihapus maka data tersebut akan disimpan ke database pada tabel tb_tv. Selain itu terdapat pilihan untuk kembali ke Menu Analisa jika tidak menggunakan Proses Tambah, sehingga dapat memilih proses yang lain yang terdapat pada halaman Analisa pada sistem ini.

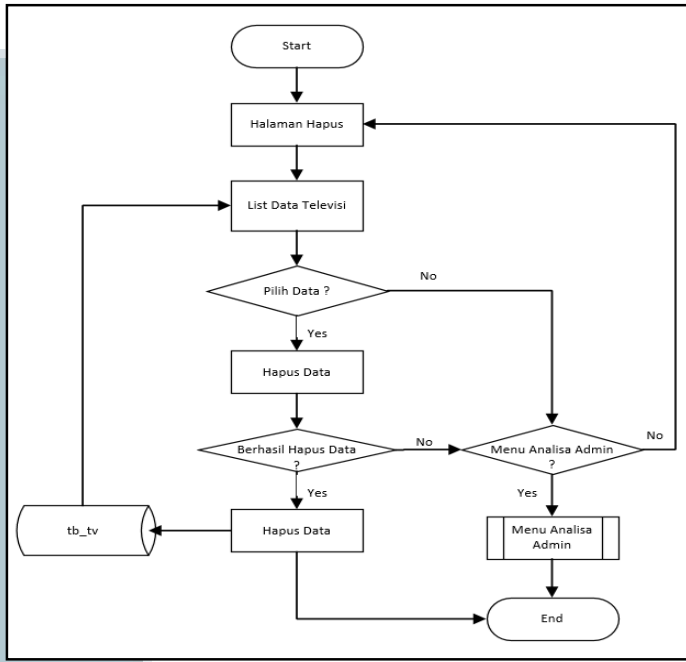

Gambar 3.8 Flowchart Proses Hapus

IV. IMPLEMENTASI DAN UJI COBA

\section{A. Implementasi Sistem}

Halaman Cari Rekomendasi merupakan halaman utama untuk user yang digunakan mencari rekomendasi televisi LED. User dapat memilih referensi dan kriteria yang diinginkan.

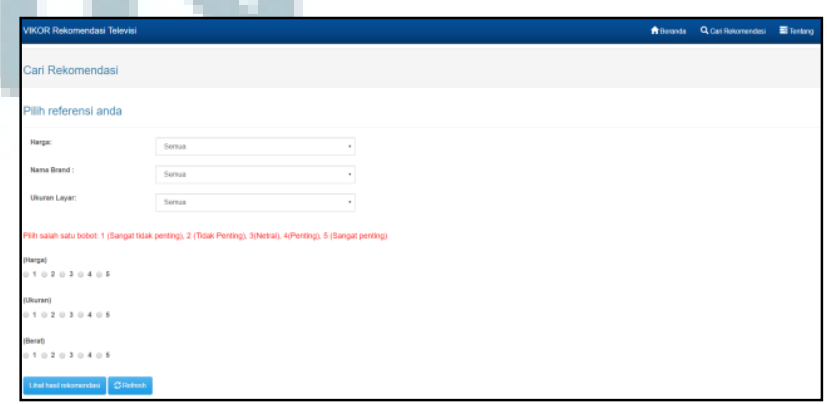

Gambar 4.1 Interface Halaman Cari Rekomendasi

Hasil dari perhitungan referensi dan kriteria yang dimasukkan user, menampilkan hasil rekomendasi tiga terbaik dari produk televisi LED. 


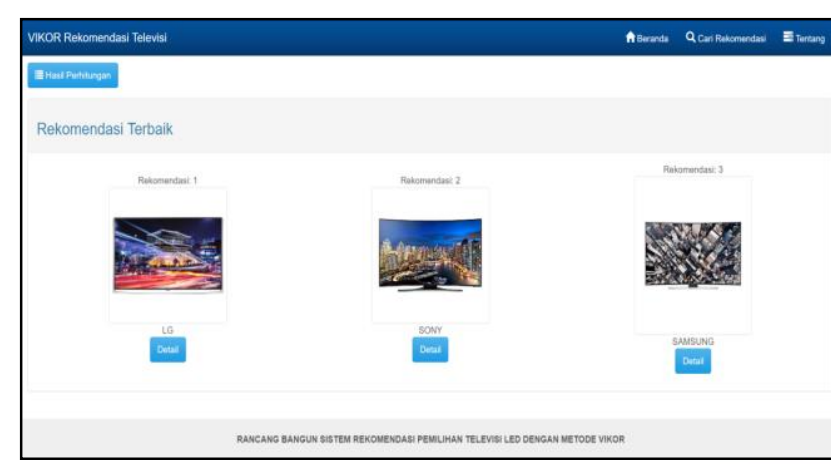

Gambar 4.2 Interface Halaman Hasil Rekomendasi

Detail Hasil Rekomendasi dapat dilihat pada halaman ini yang berisi spesifikasi dari data produk televisi yang menjadi hasil rekomendasi VIKOR.

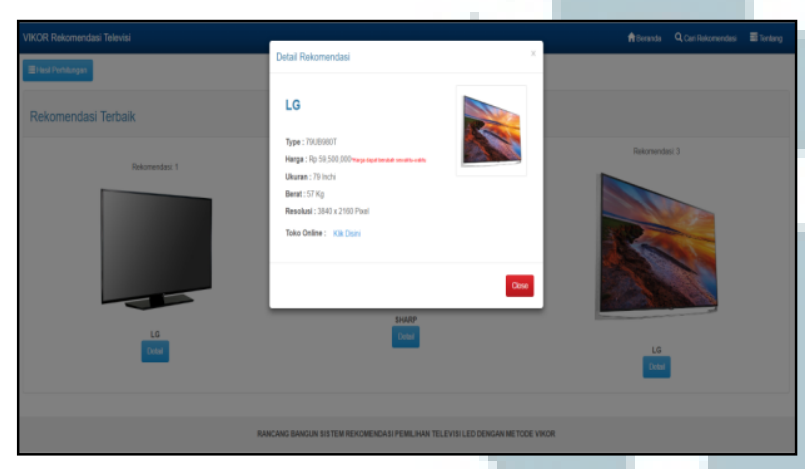

Gambar 4.3 Interface Halaman Detail Hasil Rekomendasi

Pada halaman admin dapat melihat isi dari data produk televisi pada halaman admin data televisi, terdapat tabel yang menampilkan semua data produk televisi serta terdapat gambar produk televisi di dalam tabel tersebut.

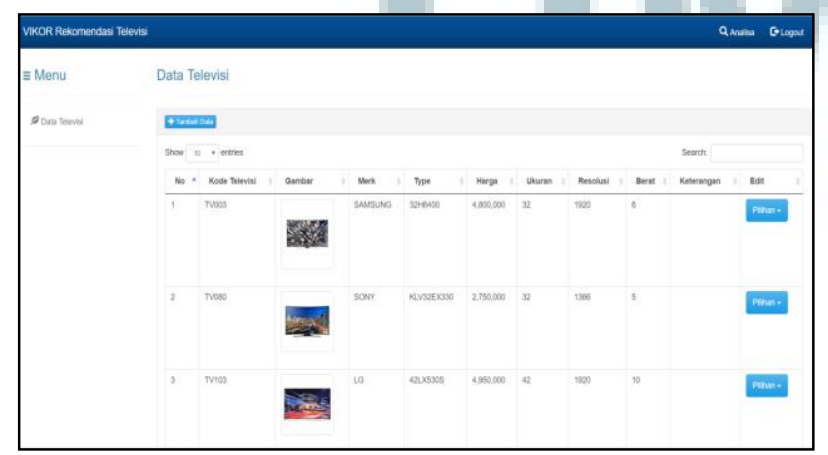

Gambar 4.4 Interface Halaman Admin Data Televisi

\section{B. Uji Coba Skenario}

Pengujian dengan responden pertama dilakukan dengan melakukan skenario pemilihan referensi dan kriteria sebagai berikut.
- Harga : 3 s/d 5 Juta

- Nama Merk : SAMSUNG

- Ukuran Layar : 32 s/d 52 Inch

Untuk pemilihan kriteria yang dipilih oleh responden sebagai berikut.

- Harga : :5

- Ukuran Layar : 2

- Berat : 4

- Resolusi : 1

Langkah pertama yang dilakukan adalah dengan melakukan seleksi berdasarkan pemilihan referensi televisi oleh responden. Terdapat tiga televisi dengan data seperti pada Tabel 4.1.

Tabel 4.1 Hasil Data Pemilihan Referensi Skenario Pertama

\begin{tabular}{|c|c|c|c|c|c|}
\hline ID_TV & Merk & Harga & $\begin{array}{c}\text { Uku } \\
\text { ran }\end{array}$ & $\begin{array}{c}\text { Bera } \\
\mathrm{t}\end{array}$ & $\begin{array}{c}\text { Resolu } \\
\text { si }\end{array}$ \\
\hline TV218 & SAMSUNG & 3.950 .000 & 40 & 11 & 1920 \\
\hline TV118 & SAMSUNG & 4.600 .000 & 40 & 10 & 1920 \\
\hline TV123 & SAMSUNG & 4.599 .000 & 40 & 10 & 1920 \\
\hline
\end{tabular}

Selanjutnya, hasil dari pemilihan bobot kriteria oleh user dan menentukan nilai Max (Nilai Terbaik) dan nilai Min (Nilai Terburuk) dari keseluruhan database televisi seperti pada Tabel 4.2.

Tabel 4.2 Nilai Bobot Kriteria dan Nilai Max Min Skenario Pertama

\begin{tabular}{|l|l|l|l|}
\hline Kriteria & Bobot & Nilai Terbaik & Nilai Terburuk \\
\hline Harga & 0,42 & 1.299 .000 & 150.000 .000 \\
\hline Ukuran & 0,17 & 90 & 20 \\
\hline Berat & 0,33 & 74 & 3 \\
\hline Resolusi & 0,08 & 3.840 & 1.366 \\
\hline
\end{tabular}

Data televisi yang ada di dalam database dinormalisasi dengan Rumus (2.1) dengan menampilkan 3 jenis data televisi sebagai contoh perhitungan manual seperti yang ditampilkan Tabel 4.3.

Tabel 4.3 Normalisasi Data Televisi Skenario Pertama

\begin{tabular}{|l|l|l|l|l|}
\hline ID_TV & Harga & Ukuran & Berat & Resolusi \\
\hline TV218 & 0,01782771 & 0,7142882 & 0,8873242 & 0,77607125 \\
\hline TV118 & 0,0221989 & 0,7142882 & 0,901409 & 0,77607125 \\
\hline TV123 & 0,0221921 & 0,7142882 & 0,901409 & 0,77607125 \\
\hline
\end{tabular}

Hasil normalisasi dikalikan dengan nilai bobot kriteria yang dimasukkan oleh user. Perhitungan dilakukan pada semua data yang telah ternomalisasi, akan tetapi sebagai contoh perhitungan dilakukan dengan 3 jenis data televisi yang ditampilkan pada Tabel 4.4.

Tabel 4.4 Normalisasi x Bobot Kriteria Skenario Pertama

\begin{tabular}{|l|l|l|l|l|}
\hline ID_TV & Harga & Ukuran & Berat & Resolusi \\
\hline TV218 & 0,00748764 & 0,121429 & 0,292817 & 0,0620857 \\
\hline TV118 & 0,00932354 & 0,121429 & 0,297465 & 0,0620857 \\
\hline TV123 & 0,00932072 & 0,121429 & 0,297465 & 0,0620857 \\
\hline
\end{tabular}


Untuk mencari Utility Measure $(S)$ dan Regret Measure $(R)$ dengan Rumus (2.2) yaitu menjumlahkan nilai yang telah ternomalisasi dan Rumus (2.3) dengan mencari nilai terbesar dari hasil nilai yang telah ternomalisasi.

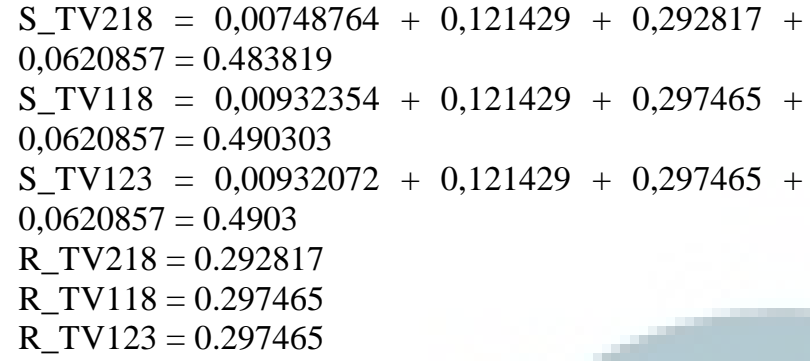

Tabel 4.5 Nilai Min Max S dan R Skenario Pertama

\begin{tabular}{|l|l|l|}
\hline & Nilai S & Nilai R \\
\hline $\operatorname{Max}\left(\mathrm{S}^{*}\right)$ & 0.580282 & 0.42 \\
\hline $\operatorname{Min}\left(\mathrm{S}^{\prime}\right)$ & 0.246805 & 0.0976056 \\
\hline
\end{tabular}

Q_TV218 $=\left[\frac{0.483819-0.246805}{0,580282-0.246805}\right] \times 0,5+\left[\frac{0,292817-0.0976056}{0,42-0.0976056}\right] \mathrm{x}$ $(1-0,5)=\left[\frac{0,237014}{0,333477}\right] \times 0,5+\left[\frac{0.1952114}{0,3223944}\right] \times 0,5=$

$0,355367+0,302752=0,658119$

Q_TV118 $=\left[\frac{0.490303-0.246805}{0,580282-0.246805}\right] \times 0,5+\left[\frac{0,297465-0.0976056}{0,42-0.0976056}\right] \times$ $(1-0,5)=\left[\frac{0,243498}{0,333477}\right] \times 0,5+\left[\frac{0.1998594}{0,3223944}\right] \times 0,5=$

$0,365089+0,309961=0,67505$

Q_TV123 $=\left[\frac{0.4903-0.1998594}{0,580282-0.246805}\right] \times 0,5+\left[\frac{0,297465-0.0976056}{0,42-0.0976056}\right] \mathrm{x}$ $(1-0,5)=\left[\frac{0,243495}{0,333477}\right] \times 0,5+\left[\frac{0.211972}{0,3223944}\right] \times 0,5=$ $0,365085+0,309961=0,675046$

Pengurutan perankingan ditentukan dari nilai yang paling rendah dengan solusi kompromi sebagai solusi ideal dilihat dari perankingan $Q_{j}$ dengan nilai terendah. Karena nilai $S_{j}$ merupakan solusi yang diukur dari titik terjauh solusi ideal, sedangkan nilai $R_{j}$ merupakan solusi yang diukur dari titik terdekat solusi ideal. Pada Tabel 4.6 menunjukkan perankingan nilai $Q$ yang diurutkan dari nilai yang terendah.

Setelah mendapat nilai $\mathrm{S}$ dan Nilai $\mathrm{R}$ maka dapat mencari nilai $\mathrm{Q}$ dengan menggunakan Rumus (2.4) dengan menentukan nilai $\operatorname{Max}\left(S^{*}\right)$ dan $\operatorname{Min}\left(S^{\prime}\right)$ terlebih dahulu dari hasil nilai $\mathrm{S}$ dan nilai $\mathrm{R}$.

Tabel 4.6 Perankingan VIKOR Skenario Pertama

\begin{tabular}{|l|l|l|}
\hline ID_TV & Merk & Nilai Q \\
\hline TV218 & SAMSUNG & 0,658119 \\
\hline TV118 & SAMSUNG & 0.67505 \\
\hline TV123 & SAMSUNG & 0.675046 \\
\hline
\end{tabular}

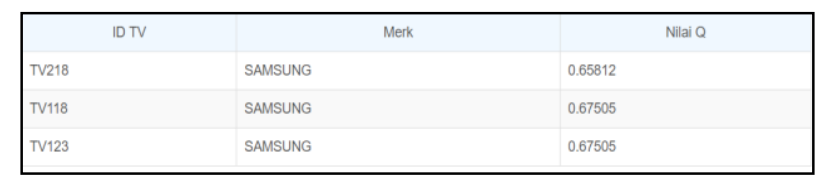

Gambar 4.5 Hasil Perankingan VIKOR Skenario Pertama dari Sistem

Hasil dari Uji Skenario Pertama dengan membandingkan hasil perhitungan manual pada Tabel 4.6 dengan hasil perhitungan sistem dengan Gambar 4.5 menunjukkan bahwa hasil akhir dari perankingan dengan menggunakan metode VIKOR sesuai dengan urutan yang sama.

\section{Uji Survei Kepuasan Pengguna Sistem}

Uji Kepuasan Pengguna dilakukan dengan menggunakan Survei kepuasan kepada 30 orang responden [24]. Kuisioner yang digunakan berisi 6 pertanyaan yang harus dijawab dan pertanyaan itu berkaitan dengan sistem yang telah dibuat berdasarkan lima komponen mengenai kepuasan pemakai sistem informasi menurut Doll dan Torkzadeh [25]. Lalu penskalaan pernyataan sikap pada kuisioner menggunakan Skala Likert [26].

Berikut ini adalah tabel dan diagram dari hasil jawaban responden pada masing-masing soal yang telah diberikan.

Tabel 4.7 Hasil Survei Kepuasan Pengguna

\begin{tabular}{|c|c|c|c|c|c|c|}
\hline & Soal 1 & Soal 2 & Soal 3 & Soal 4 & Soal 5 & Soal 6 \\
\hline 5 & 8 & 7 & 7 & 3 & 11 & 4 \\
\hline 4 & 13 & 15 & 15 & 14 & 9 & 14 \\
\hline 3 & 9 & 8 & 8 & 12 & 10 & 10 \\
\hline 2 & 0 & 0 & 0 & 1 & 0 & 2 \\
\hline 1 & 0 & 0 & 0 & 0 & 0 & 0 \\
\hline
\end{tabular}

Pada gambar 4.6 merupakan grafik dari hasil survei kepuasan pengguna dari hasil jawaban responden pada masing-masing soal yang telah diberikan.

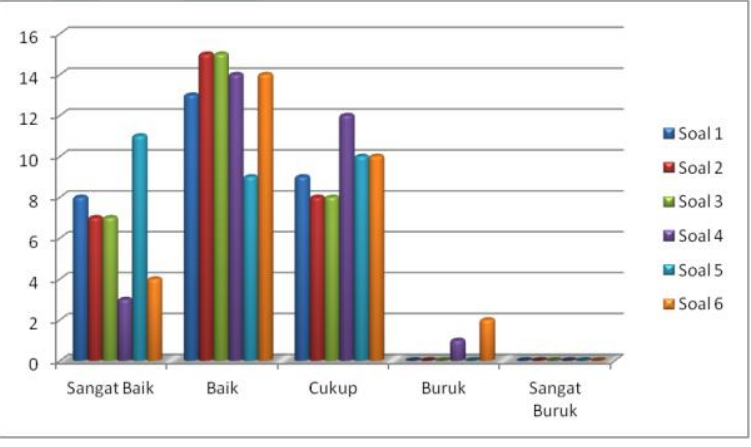

Gambar 4.6 Grafik Tingkat Kepuasan Pengguna 
Hasil dari kuisioner akan dihitung dengan menggunakan rumus Cronbach Alpha untuk menguji reabilitas dari hasil kepuasan pengguna sistem informasi [27]. Pada gambar 4.7 merupakan hasil tabel perhitungan dari hasil survei menggunakan rumus Cronbach Alpha sebesar 0,72 yang menunjukkan bahwa tanggapan responden terhadap sistem dalam kategori cukup baik [28].

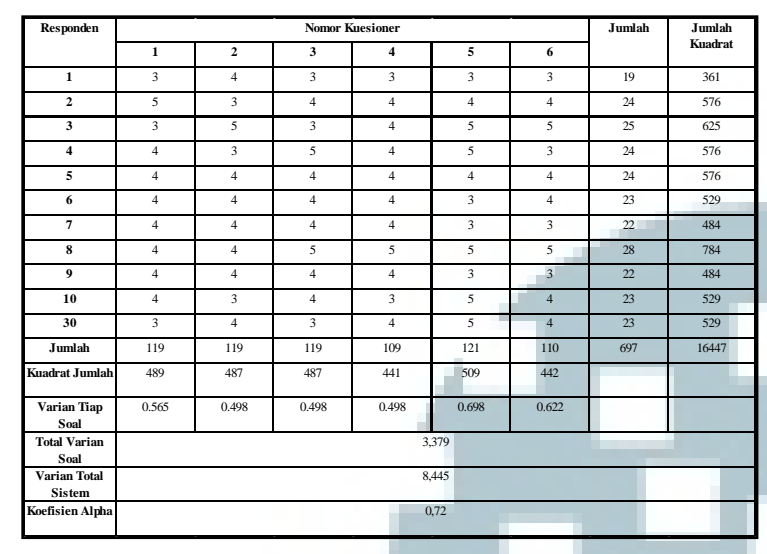

Gambar 4.7 Tabel Perhitungan Cronbach Alpha

\section{SIMPULAN}

Berdasarkan penelitian yang telah dilakukan, dapat disimpulkan bahwa rancang bangun sistem rekomendasi pembelian televisi LED dengan metode VIKOR dengan kriteria merk, harga, ukuran layar, resolusi layar, dan berat televisi telah berhasil dilakukan dengan menggunakan bahasa pemrograman PHP dan database MySQL. Dari hasil uji coba skenario yang telah dilakukan sudah dapat diverifikasi dengan membandingkan hasil perhitungan sistem dengan perhitungan manual dan survei yang dilakukan menggunakan Skala Likert dan Cronbach Alpha sebesar 0,72 yang dapat disimpulkan bahwa sistem mendapat tanggapan dari responden dalam kategori cukup baik.

\section{REFERENSI}

[1] Azhar Arsyad, M.A., (2007). "Media Pembelajaran". Jakarta: PT. Raja Grafindo Persada.

[2] MarkPlus Insight, 2014. Most Frequently Accessed Media in Last Six Month: At ten big Cities of Indonesia. Marketeers, Edisi Februari.

[3] Nielsen, 2014. "Komsumsi Media Lebih Tinggi Di Luar Jawa". Jakarta.

[4] KOMINFO, 2014. Survei Indikator TIK Rumah Tangga: Persentase Kepemilikan Radio, TV, dan Telepon di Rumah Tangga Tahun 2014".

[5] Eko, Stephanus, S.T., MMM, (2010). "LED TV Vs LCD TV Vs Plasma TV, Mana Yang Pantas Dibeli?". http://www.ubaya.ac.id/. Diakses Tanggal Akses 28 April 2016.

[6] Azis, Abdul, Hindayati Mustafidah. 2012. "Rekomendasi Pembelian Televisi Menggunakan Basis Data Fuzzy Tahani". Universitas Muhammadiyah, Purwokerto.

[7] Retno, Wahyu, Yessica Nataliana, Ramos Somya. 2012. Sistem Pendukung Keputusan untuk Merekomendasikan TV Layar
Datar Menggunakan Metode Weighted Product (WP). Universitas Kristen Satya Wacana, Salatiga.

[8] Chatterjee, P., V. M. Athawale, dan S. Chakraborty. 2010. "Selection of industrial robots using compromise ranking and outranking methods". India.

[9] Paulus, Salvius, Adhistya Erna, Silmi Fauziati. 2015. Implementasi Metode VIKOR untuk Seleksi Penerima Beasiswa. Universitas Gadjah Mada, Yogyakarta.

[10] B. Vučijak, T. Kupusović, S. MidŽić-Kurtagić, dan a. Ćerić, "Applicability of multicriteria decision aid to sustainable hydropower," Appl. Energy, vol. 101, no. June 2009, pp. 261267, 2013.

[11] Opricovic, S. dan G. H. Tzeng. "Compromise solution by MCDM methods: A comparative analysis of VIKOR and TOPSIS.” Eur. J. Oper. Res., vol. 156, no. 2, pp. 445-455, 2004.

[12] Wibowo, Eko Wahyu, dkk. (2013). Penerapan Algoritma Squeezer untuk Memberikan Rekomendasi Pilihan Lagu Berdasarkan Daftar Lagu yang Dimainkan pada Pemutar Mp3 Android. (pdf). Surabaya: Institut Teknologi Sepuluh Nopember (ITS).

[13] Fadlil, Junaidillah dan Mahmudy, Wayan Firdaus. (2007). "Pembuatan Sistem Rekomendasi Menggunakan Decision Tree dan Clustering". (pdf). Malang: Universitas Brawijaya.

[14] Kusumadewi, Sri, Sri Hartati, Agus Harjoko, Retantyo Wardoyo. 2006. Fuzzy MultiAttribute Decision Making (Fuzzy MADM). Graha Ilmu, Yogyakarta.

[15] Zimmermann, H.-J., "Fuzzy Set Theory and Its Applications", Kluwer Academic Publishers, Second Edition, Boston, MA, 1991.

[16] Ardianto, Elvinaro, 2004. "Komunikasi Massa: Suatu Pengantar". Bandung: Simbiosa Rekatama Media.

[17] Opricovic, S. (1998). "Multicriteria optimization of civil engineering systems." Faculty of Civil Engineering, Belgrade 2(1): 5-21.

[18] Opricovic, S. dan G. H. Tzeng. "Extended VIKOR method in comparison with outranking methods," Eur. J. Oper. Res., vol. 178, pp. 514-529, 2007.

[19] Sayadi, M. K., Heydari, et al. (2009). "Extension of VIKOR method for decision making problem with interval number." Applied Mathematical Modelling 33(5): 2257-2262

[20] Khezrian, M., W. Wan Kadir, et al. (2011). "Service Selection base on VIKOR method." International Journal of Research and Reviews in Computer Science 2(5).

[21] Datta, S., S. S. Mahapatra, et al. (2010). "Comparative study on application of utility concept and VIKOR method for vendor selection."

[22] San Cristobal, J. R., M. V. Biezma, et al. (2009). "Selection of Materials Under Aggressive Environments: The VIKOR method."

[23] Kusdiantoro. (2012). Analisis Usability Website Akademik Di Indonesia Menggunakan Metode Promethee, Vikor, dan Electree. Universitas Negri Yogyakarta.

[24] Roscoe, J.T. (1975) Fundamental Research Statistics for the Behavioural Sciences, 2nd edition. New York: Holt Rinehart \& Winston

[25] Doll, W.J., dan G. Torkzadeh. 1988. "The Measurement of EndUser Computing Satisfaction”. MIS Quarterly. 12 (June). pp. 259-274.

[26] Risnita. (2012). "Pengembangan Skala Model Likert". (pdf). Jambi: Institut Agama Islam Negeri Sulthan Thaha Saifuddin Jambi.

[27] Setyawan, Wahyu. (2013). "Rumus Uji Validasi dan Reliabilitas." (pdf). Jakarta. Universitas Negeri Jakarta.

[28] Gliem, Joseph A. dan Rosenmary R. Gliem. (2003). "Calculating, Interpreting, and Reporting Cronbach's Alpha Reliability Coefficient for Likert Type Scales" Paper yang dipresentasikan pada acara Midwest Research to Practice Conference in Adult Continuing, and Community Education yang diselenggarakan di The Ohio State University, Colombus pada tanggal 8-10 Oktober 2003. 